Claudio Petti, Shujun Zhang

\title{
Explaining Technological Innovation in Chinese Enterprises: Insights from Technological Entrepreneurship
}

(C) Higher Education Press and Springer-Verlag 2011

\begin{abstract}
The transformation of China into an innovation-oriented nation is now topping the agenda of Chinese government. Technological innovation is seen at the heart of this transformation, and enterprises have been called the key driving force of the innovation process. However, what are the key ingredients for such a transformation to occur? And are Chinese enterprises ready to fulfil this new responsibility? Drawing on the concept of technological entrepreneurship, this paper intends to explain technological innovation in Chinese enterprises, and attempts to develop an integrative view for research in this field, especially as related to the questions asked above.
\end{abstract}

Keywords technological entrepreneurship, technological innovation, integrative view

\section{Introduction}

Innovation, and in particular technological innovation, has been demonstrated to be a primary driver of a firm's superior profitability and competitive advantage (Cefis and Ciccarelli, 2005; Geroski et al., 1993; Roberts, 1999). However, much of the research takes the existence of technological innovation as given and

Received December 1, 2010

Claudio Petti $(\square)$

Department of Innovation Engineering, Faculty of Engineering, University of Salento, Lecce, Italy

E-mail: claudio.petti@unisalento.it

Shujun Zhang

Department of Business Administration, School of Business, Sun Yat-sen University, Guangzhou 510275, China

E-mail:mnszsj@mail.sysu.edu.cn 
examines the impact of these innovations on a firm's ability to gain competitive advantage. The questions about where these innovations come from still remain unanswered. This paper, drawing on the concept of technological entrepreneurship, intends to investigate the critical role of technological entrepreneurship in technology creation, commercialization and technology innovation in general, and in particular to examine, in the Chinese context, the key factors that facilitate the process in turning promising technologies into successful innovations and eventually into competitive advantage.

The concept of technological entrepreneurship is considered instrumental in this paper, as it brings together the technical and the commercial side of technological innovation, both focusing on their entrepreneurial components. Technological entrepreneurship concerns the identification through recognition, discovery or creation and exploitation of technology-based entrepreneurial opportunities. Drawing upon Casson (1982), Kirzner (1997), and Venkatraman and Sarasvathy (2001), we define technology-based entrepreneurial opportunities or technological opportunities as the possibilities to create new products, which originate from the divergence of beliefs towards the future value of previously un-exploited technologies.

In the Chinese context, where much emphasis has been put on increasing (indigenous) innovation - and especially technological innovation capacitythrough construction of an enterprise-centred national innovation system (Schaaper, 2009), the concept of technological entrepreneurship is of particular relevance. Technological entrepreneurship is in fact the bridge between technology development and commercial exploitation. Moreover, technological entrepreneurship turns out to be a more appropriate concept than technological innovation in explaining the innovation activities undergoing in Chinese enterprises.

In addressing this issue, this work attempts to develop a comprehensive understanding of technological innovation and entrepreneurship in Chinese enterprises, with particular reference to factors enabling or inhibiting these activities. In order to do so, we develop an integrated view that accommodates individual, firm and system-level factors and the contributions of different theoretical perspectives.

This paper is organized as follows. After a brief introduction to technological entrepreneurship and its implications for this work, the paper will illustrate the Chinese system for technological entrepreneurship, with particular reference to the role of enterprises and their innovation model. Also, as other players are involved, their contributions to Chinese enterprises and the distinguishing features of this system will be discussed. Then an integrated view of technological entrepreneurship in Chinese enterprises will be presented in detail. 
The conclusions will summarize this work's contribution and put forward directions for future research.

\section{Theoretical Background: The Entrepreneurship Side of Technological Entrepreneurship}

Technological entrepreneurship encompasses all of the activities related to the identification of potential entrepreneurial opportunities, which arise from technological developments, and the exploitation of these opportunities through successful commercialization of innovative products. Technological entrepreneurship has been characterized in different ways and at different levels of analysis, either as a system (Abetti, 1992; Kenney and Von Burgh, 1999), a policy (Zhang et al., 2008; Yu et al., 2009), a strategy (Gans and Stern, 2003), a process (Shane and Venkataraman, 2003; Antoncic and Prodan, 2008; Petti, 2009) or an individual attitude (Dorf and Byers, 2005; Suzuki et al, 2002).

A central feature of the technological entrepreneurship concept is the concept of entrepreneurial opportunities, and more specifically, technology-based entrepreneurial opportunities. Entrepreneurial opportunities have been defined as possibilities to create new economic artefacts originating from the divergence of beliefs towards the future value of new or existing idea(s) and invention(s) and related actions for the achievements of one or more ends (Venkatraman and Sarasvathy, 2001). The heterogeneity of beliefs about the value of new or existing idea(s) and invention(s) when they are converted from inputs into outputs, and especially the action upon un-exploited opportunities (Kirzner, 1997; Casson, 1982), is the characterizing element of entrepreneurial opportunities and entrepreneurship overall.

When new or existing ideas and inventions concern technologies, i.e., "theoretical and practical knowledge, skills, and artefacts that can be used to develop products and services as well as their production and delivery systems" (Burgelman et al., 2004: 2), and in particular un-exploited technologies, emerge, we then have technology-based entrepreneurial opportunities or technological opportunities. Therefore, whenever a divergence of belief about the future value of a (new or existing) technology emerges, a technology-based entrepreneurial opportunity comes to existence. As a matter of fact, as argued by Venkataraman and Sarasvathy (2001), this kind of opportunities not only exist at all levels of an economy, but also they are extremely context-specific: "(opportunities) do not necessarily lie around to be discovered by serendipitous entrepreneurs who stumble upon them...entrepreneurial opportunities are often residual of human activities in non-economic spheres and emerge contingent upon actions by conscious entrepreneurs who continually strive to transform the outputs of these non-economic activities into new products and firms." (Venkataraman and 
Sarasvathy, 2001: 652).

This consideration leads directly to the central question of technological entrepreneurship research: How technological opportunities are identified and exploited? At the very essence, this is the result of a combination of conscious individual entrepreneur's actions and collective efforts within a context made of a specific set of local conditions and constraints. Therefore, it should not be surprising if technological entrepreneurship has been characterized as a complex phenomenon, spanning multiple disciplines and levels of analysis (Shane and Venkataraman, 2003; Phan and Foo, 2004; Petti and Zhang, 2011).

In particular, concerning the multi-disciplinary nature of technological entrepreneurship, there are now strong theoretical arguments that highlight the interrelationships among technology, innovation, entrepreneurship and strategy (Hitt et al., 2001; Venkataraman and Sarasvathy, 2001; Ireland and Webb, 2007; Schendel and Hitt, 2007). As a matter of fact, there is now wide spread agreement that changes in technology (technological advances) are among the key sources that contribute to the market imperfections which lead to the formation of entrepreneurial opportunities (Kirzner, 1973), and the base for most innovations (Schendel and Hitt, 2007). Innovation on the other hand is recognized to be both the primary driver of value creation, which is realized through the provisioning of entrepreneurial opportunities to exploit, and the primary driver of value appropriation, which is through the generation of competitive advantages and above-average returns from the exploitation of entrepreneurial opportunities (Roberts, 1999; Barney, 2007).

Concerning the different levels of technological entrepreneurship, at the individual level, the focus is on scientists/entrepreneurs, venture capitalists, and other individuals that initiate and drive technological innovation. At the organizational level, research examines technological teams, structures, processes, and inter-organizational linkages that impact value creation. At the system level, it is about the resources exchanged among different players in the ecology of value creation, which includes the governing factors such as government's technology and competition policy, industry standards, and the economics of geographical locations (Phan and Foo, 2004).

When undertaking technological entrepreneurship-related research, there is a need to adopt a micro-macro perspective and to rely on insights of different theories. As a matter of fact, Petti and Zhang (2011) in a recent work have demonstrated that the conditions and drivers leading to the identification and exploitation of technology-based opportunities for value creation are rooted in different theories, namely entrepreneurship, technology innovation management, strategic management, social capital/network and institution-based perspectives.

Each of these theories offers important insights in one or more aspects of technological entrepreneurship and provides a specific perspective in addressing 
the following issues: (1) How, by whom, and with which effects opportunities to create future goods and services are identified, evaluated and exploited (Shane and Venkataraman, 2000)? (2) The influence of organizational structures, processes, and people on the development and commercialization of new products (Zirger and Maidique, 1990), and how to deploy technological capabilities to exploit the identified opportunities? (3) What are the attributes of those capabilities that help technological firms achieve and maintain superior performance and competitive advantage (Rumelt, Schendel, and Teece, 1994)? (4) What are the role and structural configurations of external networks in the identification and exploitation of technology-based entrepreneurial opportunities (Cooper, 2001; Tsai, 2000)? (5) How formal and informal institutions can influence the formation of technology-based entrepreneurial opportunities and the capability of enterprises to exploit them (North, 1990)?

From what is stated above, it is clear why we espouse a micro-macro and multi-disciplinary perspective in our attempt to investigate technological the entrepreneurship in Chinese enterprises. What may be not clear is the scope of technological entrepreneurship concept and research. More specifically, three questions emerge: (1) Should it only focus on new, emerging and sophisticated technologies, or should it include also existing, mature and even simple technologies? (2) Should it cover only high-technology enterprises and industries or should it also consider medium/low technology ones? (3) What about the other kind of innovations?

Zhang et al. (2008) identified two main streams of research in the literature about technological entrepreneurship: one is the study of high-technology entrepreneurship (Smilor et al., 1989; Bahrami and Evans, 1995; Kenney and Von Burg, 1999), and the other explores public research commercialization and spin-off of universities (Smilor et al., 1999; Gregorio and Shane, 2003; Hindle and Yencken, 2004). Notwithstanding most of this literature focuses on the first kind of technologies, the privileges of high-tech enterprises and industries, and the critical role of product innovations, the above questions are in fact rhetorical questions. This paper argues that the research of technological entrepreneurship should cover and incorporate all types of technologies, enterprises and industries, and can be extended to include other types of innovation than product innovations.

To a large extent, the high-tech focus of most of the current technological/ technology entrepreneurship research is not only a matter of fashion or opportunity (Robertson and Von Tunzelmann, 2009), but also a matter of having misunderstood the concept of technological entrepreneurship, in particular as related to the difference with technological innovation and technology commercialization.

As a matter of fact, technological opportunities are more linked to the matching 
of the potential applications of a technology with a potential market need or space rather than to the inherent characteristics of the technology in itself, such as its newness or sophistication. Moreover, entrepreneurship is concerned with both opportunity identification and exploitation activities rather than with commercial exploitation through development and commercialization of new products, processes and knowledge. Therefore, technological entrepreneurship is different from both technological innovation and technology commercialization, due to its focus on matching rather than novelty (see also Hindle and Yencken, 2004) and its focus on both antecedents and consequences rather than simply on consequences. To sum up, technological entrepreneurship is a bridging concept between technology innovation and commercialization concepts, bringing together the technical and commercial worlds in a profitable way (Burgelman et al., 2004).

Finally, notwithstanding the technological product innovation-centric conception of technological entrepreneurship, it can also include technologyrelated process innovations (Tushman and Anderson, 1997), organizational and marketing innovations, given these innovations are introduced into the market in the form of new services. Examples of such kind of innovations are the commercialization of IT-based processes, such the UPS's logistics, and organizational methods such as "IBM's Global Services" or e-Commerce solutions such as "e-Bay stores." As we will see in the following section, the conceptualization of technological entrepreneurship advocated here is particularly useful in the Chinese context.

\section{The Chinese System for Technological Entrepreneurship}

Technologicall entrepreneurship is affected by a specific context made of a mix of specific conditions. These conditions affect the ways in which technological opportunities come to existence and the capabilities employed by the enterprises to exploit them through new products development and commercialization. Technological entrepreneurship is thus the result of a system of interactive players performing a number of activities concerned with the transformation of raw technologies into marketable products under a set of specific constraints. These players are the entrepreneurs and their enterprises; investors, other professional service firms and talented individuals; central and local government agencies; research and higher education institutions; and the community in general, in particular (national and international) standard bodies or industry/ consumers associations.

Investigation of technological entrepreneurship in Chinese enterprises requires the study of such a system, which might be referred to as the Chinese system for technological entrepreneurship. In particular, a great emphasis should be put on 
study of (1) the role of enterprises within such a system, and (2) who other players are and how they influence Chinese enterprises' technological entrepreneurship activities. This paper tries to shed light on these issues by discussing the role of Chinese enterprises, foreign enterprises, government agencies, government research and higher education institutions, transnational communities, investors and other relevant organizations. In doing so, we will also highlight the specificities of the Chinese system for technological entrepreneurship.

The role of enterprises in China is not substantially different from that of their counterparts' in other countries. What differs might be the ways in which it is fulfilled. More specifically, the role of enterprises is to exploit new or existing technologies to innovate or improve their products (i.e., goods and services) and production processes. The main ways in which this role is performed is to craft profitable business models that are able to realize selected technologies value creating potential. In China, the role of enterprises is becoming more and more important, but they are performing this role more on the entrepreneurship than on the innovation side.

According to the government plans and statistics, Chinese enterprises are expected to be the largest $R \& D$ performer and the key driving force in the country's efforts to become an innovation-oriented nation by 2020. As a matter of fact, enterprises (especially large and medium ones) take up 70\% of the country's R\&D expenditure and enjoy a number of preferential policies and specific incentives to engage in technological innovation activities. Though most of the R\&D expenditure is dedicated to experimental development instead of applied research, Chinese enterprises innovation capacity is portrayed as being weak (Guan et al., 2006; Li-Hua and Khalil, 2006; Wilsdon and Keeley, 2007; Chen and Yuan, 2007; Dobson and Safarian, 2008; OECD, 2008; Schaaper, 2009; Zhang et al. 2009) or at best in transition (Altenburg et al., 2008; Xie and White, 2006). In fact, the vast majority of Chinese enterprises are following an incremental innovation model that is more cost and market-oriented rather than technology-oriented.

The distinctiveness of Chinese enterprises is that they do not rely on radical technological development, but mainly on incremental adjustments or mere matching of existing technologies. This is manifested by improved and adapted products in responding to specific local market needs - mainly rural and low end markets (lowering costs) or niche markets (customizing features) - and the increased response to the market. This kind of innovation has been called in different ways as market-oriented innovation (Liu, 2008), secondary business model innovation (Wu et al., 2010) or creative imitation. In any case, whichever the definition is used, all of the characterizations converge on the consensus that innovation of Chinese enterprises is incremental rather than radical, business 
model oriented rather than technological components oriented, more focused on flexibility than on competence development.

It appears that Chinese enterprises are intensely "technologically entrepreneurial," in the sense of being particularly capable to recognize and exploit the commercial opportunities of (mainly existing) technologies and markets. That is why we believe the concept of technological entrepreneurship gives a more realistic picture of the kind of innovation undergoing in Chinese enterprises. The fact that innovations in Chinese firms are not radical neither means that they are not innovative at all, nor does it mean that they will not be successful commercially.

In fact, Chinese firms have achieved huge success by adopting their incremental innovative strategy. Its commercial success is at the same time one of the main reasons of the resilience of current Chinese enterprises' innovation model, and one of the main factors that leads to its evolution, since it provides the necessary resources to engage in internal technology upgrading (both through internal development and acquisition). However, Chinese enterprises' innovation efforts have shifted towards acquisition and limited adaptations of existing technologies to produce cheaper, simpler, good-enough and customized products rather than on the development of radically new ones. This situation might be interpreted as a transitory state from incremental, imitative, market-oriented or secondary business model innovations towards more significant, original and technological-oriented innovations. As a matter of fact, the country's technology champions such as Huawei, ZTE and Lenovo, all started from meeting the needs of the local (rural) markets with foreign products and technologies and then gradually scaled up in adapting and finally developing their own capabilities, products and technologies (Liu, 2008).

Whatever the degree of imitation is, usage or adaptation of the model depicted above presupposes that the technologies used should be obtained elsewhere. That is why foreign enterprises come into play. The strong relevance of foreign enterprises is one of the distinguishing features of the Chinese technological entrepreneurship system. Foreign enterprises, through exports, licences, localization of R\&D labs and cooperative ventures, are significant providers of technologies, innovations and managerial skills. Notwithstanding the government's drive to develop endogenous innovation, technology imports, international outsourcing and foreign $R \& D$ labs are still playing a very important role. An example is that $50 \%$ to $70 \%$ of the manufacturing cost of a Chinese PC is made up of licence fees to Microsoft and Intel (OECD, 2008). Foreign-invested enterprises hold $29 \%$ of the invention patents of the country, and their development expenses, sales revenues and exports amount of the new products account respectively for $31 \%, 41 \%$ and $60 \%$ of those of the whole country in year 2009. 
Another main provider of technologies and innovations is governmental research institutes (GRI). The relevance of these actors (inherited from the pre-opening reform and the planned economy) is another distinguishing feature of the Chinese system for technological entrepreneurship. GRI provides mainly basic, strategic and applied research as well as technology diffusion and commercialization in the enterprises' sector. For example, Chinese Academy of Science (CAS) applied research institutes and the State Engineering Technology Research Centers (SETRC) also play important roles. These centers are specifically oriented to develop know-how concerning various series of products for a certain industry.

Since most of the Chinese enterprises do not have their own research laboratories, CAS applied research institutes and SETRCs are both regarded as important solution providers for technology development and innovation, and with particular reference to SETRCs, for technology digestion and transfer for a specific high-tech industry. For instance, SETRCs do various demonstration projects with the support of government, and provide recommendation for certain product or technology. Besides, there are other governmental institutes and research centers such as the Development Research Center of the State Council (DRC), the Chinese Academy of Engineering, and the Chinese Academy of Social Science, which provide expert analyses and advice to policy makers on technological, economic, and policy issues.

Central and local governmental institutions in China still play a relevant role in research and development activities for Chinese enterprises. They are not only the providers of relevant policies, regulations, programs and incentives (such as the IP law, the 863 Program, and the taxes exemptions on innovation activities and technology imports), but also the orchestrators of science-industry linkages (such as the Torch Program). Those institutions exert their direct influence through administrating research activities of large and numerous state-owned enterprises.

Among these institutions, the main ones are the National Development and Reform Commission (NDRC), the Ministry of Science and Technology (MoST), the Ministry of Education (MoE), together with a number of other Ministries that operate their own research institutes and universities (such as the Ministry of Industry and Information Technologies). Bodies like the State Intellectual Property Office (SIPO) and the Ministry of Finance (MoF), which regulates respectively intellectual property rights and public procurement, are also key players at the central level. It is also worth mentioning that the local governments (i.e., Provinces, Provincial-level Municipalities and Cities) and the local bureaus of central government structures - such as local Sciences and Technologies Bureaus of MoST or local Development \& Reform Commissions linked to the NDRC) are of no less importance than those at the central level.. 
Another element is the role of the Chinese transnational community. This community is made of thousands of overseas Chinese, expatriates, and Argonauts (Saxenian, 2006) that live, study/ied, work/ed and travel back and forth from technologically advanced part of the world (mainly Silicon Valley). These individuals not only act as critical links in boosting local technology development capacities through transfer of knowledge and relationships, but also contribute to the Country's technological upgrading through the start-up of new enterprises, patenting, setting up of research labs and institutes, attraction of foreign direct investments and bringing the managerial skills. Evidence is that from 1978 to 2005, more than 700000 Chinese went abroad for study or work, while more than 180000 Chinese who were educated in U.S. returned to China. During 2000-2002, more than 718000 highly skilled Chinese-born residents were in OECD countries, $57 \%$ of which were in U.S. (Schaaper, 2009), serving as a strong force in the transnational community.

Another peculiar characteristic of the system is the role of investors. Whereas investors in many countries are usually private, in China, a good number of investors are public. More specifically, due to the underdevelopment of the banking system to finance innovation activities, the source of venture capital is characterized by strong government involvement. This involvement takes various forms, such as the support from Science and Technology Industrial Parks, Business Incubators and specific High-Tech program. The involvement is also reflected by the establishment and management of specific funds such as the "Innofund" for small technology-based firms.

At the same time, some non-governmental sources, in particular foreign venture capital and some domestic private enterprises, are becoming more and more important funding sources, especially for high-tech industries. However, the system is still affected by a serious shortage of funds and professionals, especially at the early stage of investments. Both public and private investors need professionals with the experience and skills to identify and invest in high-risk investments and to accompany and finance technology firms over their development stages. In other words, there is a serious lack of business angels and business angels groups (Linton, 2006) that have proven to be beneficial in the U.S. for new ventures for raising funds (Olivier, 2009).

Besides these players, higher education institutions and in particular "entrepreneurial universities" like Tsinghua University, make significant contributions not only in providing knowledge and skilled labor force for enterprises but also, and may be more in China than in other countries, help technology diffusion and enterprises creation. According to OECD (2008), over the years, many Chinese universities had accumulated experiences in downstream activities (applied research and development of prototypes), had created their own enterprises (more than 4500 University-run enterprises in 
2004) and incubated more than 6000 enterprises (as per 2005 statistics) in their incubators.

Finally, industry associations and national and international standard bodies should be taken into account. Basically, their role in the process is to provide a variety of means to facilitate technological entrepreneurship, ranging from technological standards (such as the Intelligent Grouping and Resource Sharing for the homonymous standard IGRS or the $3 \mathrm{G}$ forum for the TD-SCDMA) to linkages with the S\&T Community at all levels, such as the China Association for Science and Technology.

Fig. 1 synthesizes the Chinese system for technological entrepreneurship, highlighting the role of Chinese enterprises and the contributions of other players involved in technological entrepreneurship activities. The dimension of the arrows indicates the significance of contributions discussed, whereas the circled line represents the (National) borders of the system.

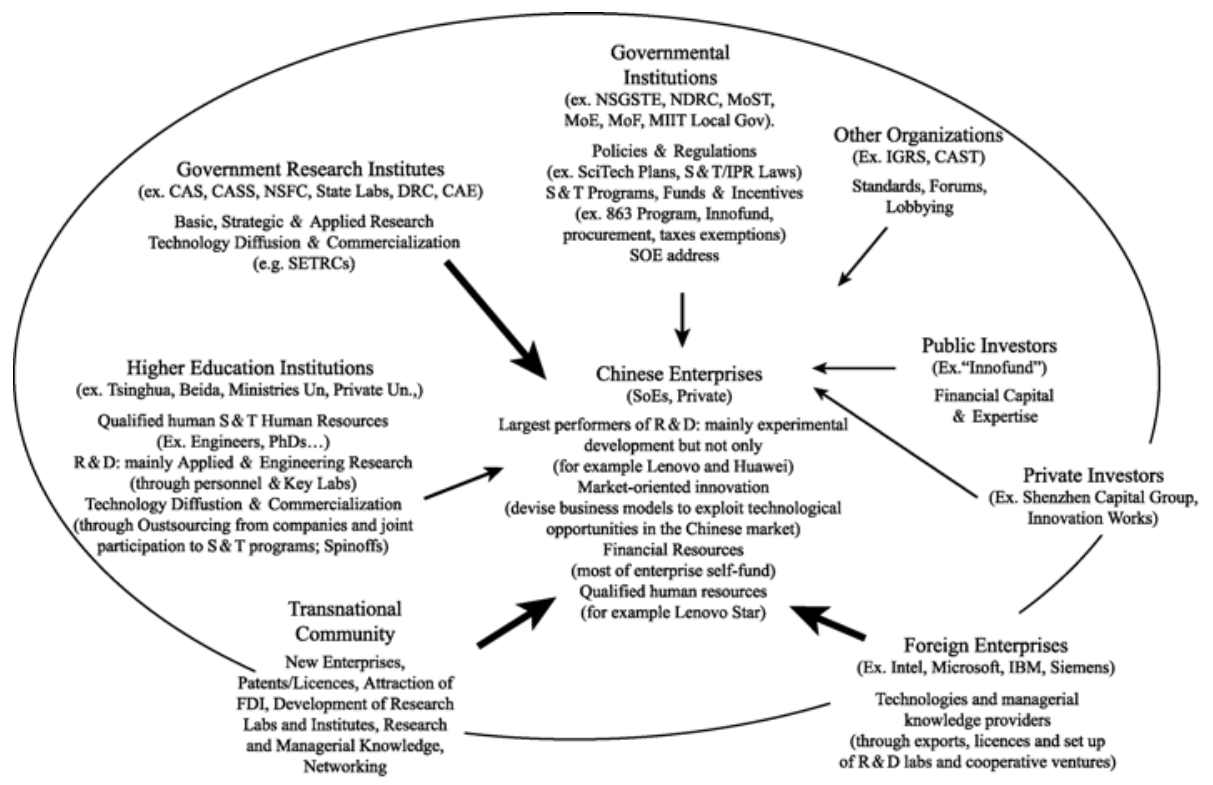

Fig. 1 The Chinese System for Technological Entrepreneurship

The provision of a supportive environment in which to operate and co-operate with other players (GRI, in particular) is also important. The State Middle-Long Term (2006-2020) S\&T Development Plan in China, which promotes of IPR standards and IPR-protected technologies as well as introduces fiscal incentives and public procurement to support innovative activities, is a preeminent example of such a role.

What discussed above highlights that technological entrepreneurship in China 
is a set of distributed activities. Enterprises are responsible for the most important part, i.e., the transformation of technologies in new products, services and businesses. However, returns on this activity are dependent upon a number of governmental institutions, governmental research institutes and higher education institutions, investors and other players that directly and indirectly influence Chinese enterprises activities, respectively:

(1) The supply of qualified human capital and knowledge, whereby qualified means able to match the real needs of the enterprises in which they are supposed to work or be applied, with particular reference to innovation. This is particularly relevant for small and medium private-owned enterprises, whose major difficulties are attracting and retaining the talents necessary for their innovation activities.

(2) The availability of venture capital and business expertise. These imply the need of setting up favourable environment for innovation investments either through traditional planning - such as the responsibility given to China Development Bank and China Import-Export Bank to provide soft loans and special accounts to high-tech enterprises by the above mentioned Sci-Tech plan or Innofund program for small technology-based private enterprises - or with more market-based mechanisms such as the creation of the ChiNEXT market in Shenzhen.

(3) Discussion forums in which the enterprises and other relevant players can meet, debate and jointly establish common standards and rules. This is helpful for the creation of a mutually beneficial technological entrepreneurship environment.

\section{An Integrated View of Technological Entrepreneurship in Chinese Enterprises}

In the previous section, we looked into the issue of technological entrepreneurship in Chinese enterprise from a system perspective, depicting what we have called the Chinese system for technological entrepreneurship. We advocate that this will greatly influence Chinese enterprises' technological entrepreneurship activities and outcomes. It is suggested that many of the influencing factors are at the system level, such as the negative influence of weak and uncertain protection of intellectual property rights and contracts enforcement on innovation activities (Xie and White, 2006, Chen and Yuan, 2007; Schaaper, 2009) and collaboration (Zhang et al., 2008), the positive effects on technological innovation and entrepreneurship of specific government industry, technology and entrepreneurship policies and institutional support in general (Liu, 2008; Zhang et al., 2008; Li and Atuahene-Gima, 2001), the negative influence of the exceptional market size and growth of the Chinese market (Zhang et al., 2009; 
Chen and Yuan, 2007) or the positive influence of technology transfer (Guan et al. 2006) on innovation capacities

However, there are also a number of other studies that reveal enterprises-level factors, such as the lack of adequate absorptive capacity especially as related to knowledge assimilation and adoption (Liu 2008; Dobson and Safarian, 2008; Xie and White, 2006; Chen and Yuan, 2007), too much reliance on innovation outsourcing/import of technologies, and too much dedication to acquisition of equipment rather than know-how (Liu, 2008; Chen and Yuan, 2007; Dobson and Safarian, 2008), the lack of incentives such as competition in SOEs (Liu, 2008, OECD, 2008) and innovation culture in enterprises (OECD, 2008; Xie and White, 2006; Baark, 2001), learning prowess and knowledge integration capabilities (Liu, 2008; Wang et al., 2004, 2006).

Among these studies, Wang et al. $(2004,2006)$ and Li and Atuahene-Gima (2001) adopt a more integrative view studying both enterprise level factors and system level factors. For example, Wang et al. $(2004,2006)$ analyzes the effect of internal technological, market and integrative capabilities (what we see as the constituents capabilities of technological entrepreneurship) on firm's innovation and overall performance, taking into account the moderating effects of environmental turbulence. $\mathrm{Li}$ and Atuahene-Gima (2001) goes further in considering also the moderating role of institutions and external networks on the relationship between product innovation strategies and Chinese enterprises' performance, taking into account the moderating effects of environmental turbulence, dysfunctional competition, institutional support and relationshipased strategies.

The above mentioned studies are consistent with the international technological entrepreneurship-related literature, which suggests that factors influencing a firm's technological entrepreneurship could be situated both inside (Doganova and Eyquem-Renault, 2009; Antoncic and Prodan, 2008) and outside the enterprises boundaries (Elfring and Hulsink, 2003; Tomes et al., 2000; Keeley and Von Burgh, 1999). They are contingent upon (formal and informal) institutions (Gans and Stern, 2003; Allen, 2003) and environmental factors (Castrogiovanni, 1991).

Therefore, we suggest that the development of technological entrepreneurship for Chinese enterprises is influenced by four main categories of factors: internal capabilities, external networks, institutions and overall environment.

Internal capabilities refers to the capabilities related to the recognition, discovery and creation of technological opportunities (i.e., entrepreneurial capabilities) and the exploitation of these opportunities through the development of compelling value propositions and innovative business models (i.e., strategic capabilities). Entrepreneurship and strategic management research provides a number of such capabilities, more in particular: entrepreneurial cognition 
(Alvarez and Busenitz, 2001; Venkatraman and Sarasvathy, 2001) orientation (Lumpkin and Dess, 1996; Covin and Slevin, 1991; Miller, 1983), absorptive capacity (Zahra and George, 2002; Cohen and Levinthal, 1990), and dynamic capabilities (Teece, 2007; Eisenhardt and Martin, 2000; Teece, Pisano and Shuen, 1997; Teece and Pisano, 1994).

However, if technological opportunities are "residual of human activities in non-economic spheres" (Venkataraman and Sarasvathy, 2001: 652), these opportunities can be identified from a number of external sources, such as familiar industries and businesses, social and professional networks, customers, universities technology transfer offices, and government agencies. This highlights the relevance of external networks and in particular the attributes that make these networks conducive to get the necessary information and knowledge to recognize and discover commercial opportunities of new or existing technologies, and to secure the resources and capabilities needed to transform those opportunities into real profits. The government policies and initiatives, laws, regulations and standards are paramount-and in some case determinant - in making technological entrepreneurship efforts of enterprises worthwhile. Besides, a key role is also played by local entrepreneurial, specific industry and organizational culture. The institution-based perspective is an essential driver for the investigation of a number of moderating factors that can influence Chinese enterprises' technological entrepreneurship capabilities.

Environment refers to all of the macro-environmental forces and characteristics that may influence technological entrepreneurship, for example, environmental turbulence, market size and growth (i.e., environmental munificence), market and technological turbulence and trends. They are of all critical importance in nurturing the technological entrepreneurship.

How these factors matter and interact in practice can be illustrated by the case of Deqingyuan Ecological Farm. Apart from hosting more than 3 million chickens and producing $71 \%$ of the organic eggs sold in the Beijing market, this enterprise fulfils the power needs of 10000 families in Beijing, Tianjin and the Inner Mongolia, with electricity converted from chicken manure. Using biogas instead of coal cuts its $\mathrm{CO}_{2}$ emissions by about 95000 tonnes a year (Xinhuanet, May $4^{\text {th }}, 2009$ and IFC). The internal capabilities component played a significant role in: 1) the detection of the market demand for producing high-quality eggs, and the potential entrepreneurial opportunities emerging from the increasing concerns of Chinese government and public opinion on environment, climate change and renewable energy issues; 2) the recognition of the opportunity to build an anaerobic digester fuelled by chicken litter to produce biogas that allows to match eggs-laying operation with the production of clean energy and to exploit the new Certified Emission Reductions (CERs) market; 3) the design of a new business model able to combine egg production with renewable energy 
production, fertilizers and CERs production that transformed the technological opportunity identified into real economic, environmental and social value.

The external network component plays a significant role in both the recognition of the technological opportunity and the securing of resources for its exploitation. Previous employment relationships with the government, and a mix of ties with international agencies and local community have been fundamental in gathering information, evaluating the potentiality of opportunities and securing extra-financing for the initiative (including IFC, a member of World bank Group that supports the development of the biogas plant with investments and purchasing contract of CERs), and also legitimacy and support for the initiative.

Fig. 2 summarizes the main factors mentioned, their relationships with technological entrepreneurship and competitive advantage, and the integrative (multi-level and multi-disciplinary) nature of this research.

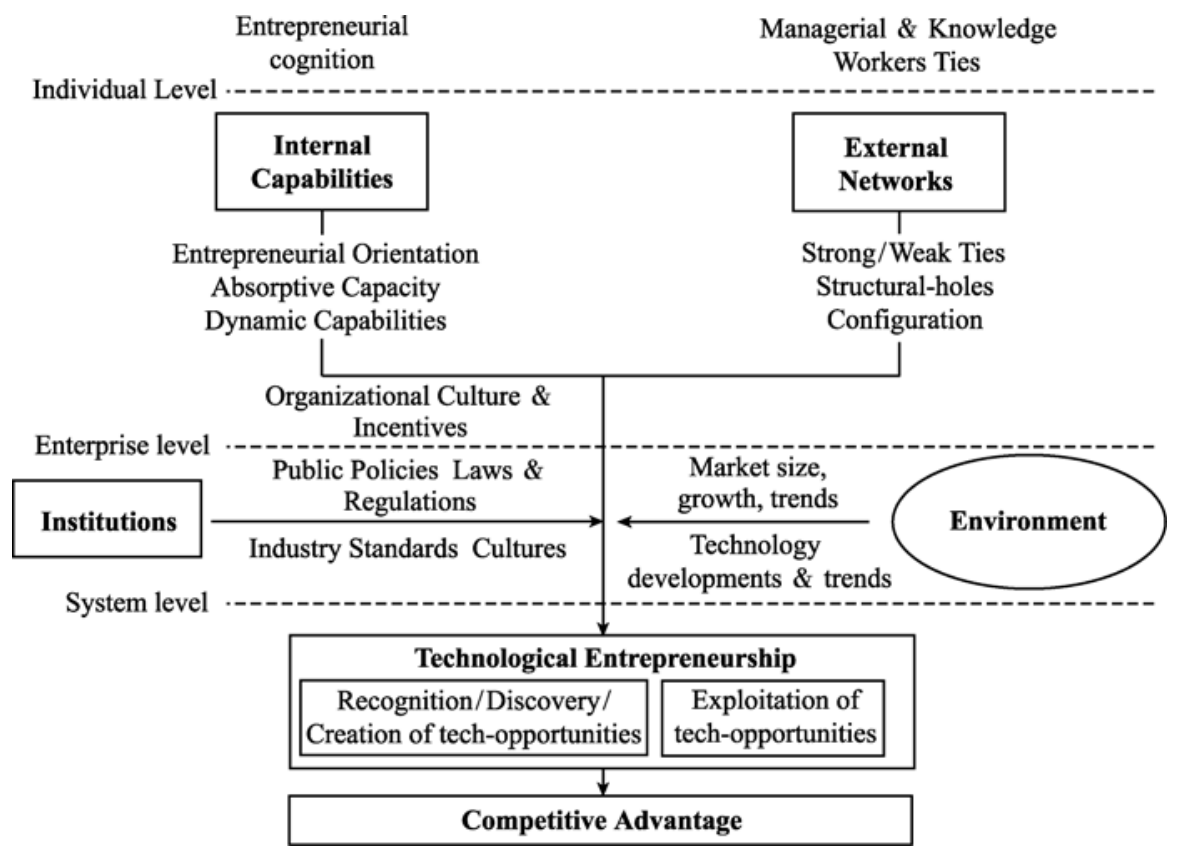

Fig. 2 Technological Entrepreneurship in Chinese firms: An Integrative View

\section{Conclusion}

This paper draws on the concept of technological entrepreneurship to explain technological innovation in Chinese enterprises and tries to offer an integrative view to for research development in this field, with particular focus on the factors influencing technological innovation and entrepreneurship in Chinese 
enterprises.

This paper contributes to the understanding of technological innovation and entrepreneurship in Chinese enterprises in three aspects. First, we focus our attention on the entrepreneurship component of technological innovation, and discussed the importance of this component for the success of enterprises' new product development and commercialization. Second, this paper employs an institution-based perspective to demonstrate the systemic nature of technological entrepreneurship. Third, we offer a description of the system for technological entrepreneurship in Chinese context.

For studies of technological entrepreneurship in Chinese enterprises, three issues should be given priority: (1) How are opportunities that transform technologies into new products (i.e., goods and services) recognized, discovered or created? (2) How to assemble the necessary resources, and manage the relationships among science, engineering and management, to develop new products and exploit these opportunities on the market? (3) How to identify and explore technology-based opportunities? This paper offers insights to the last issue but still has limitations such as the limited empirical validation for the influencing factors mentioned and their relationships with technological entrepreneurship, especially for the Chinese context.

The above questions provide directions for future research. First, future research could put more attention on non-technological innovations, and include medium and low-tech sectors as well as on service sectors in the sample. Second, future research could include the role of individuals (both entrepreneurs and knowledge workers). Third, future research should focus more on a comprehensive understanding of micro-macro links rather than single components.

Acknowledgements This work is supported by the Science \& Technology Fellowship Programme in China, which is financed by the European Commission (Reference: EuropeAid/127024/L/ACT/CN), the National Philosophy and Social Science Foundation of China (No. 07CJY008), Guangdong Soft Science Program (No. 2010B070300039), and a grant from Sun Yat-sen University (No. 3161112).

\section{References}

Abetti, P. R. 1992. Planning and building the infrastructure for technological entrepreneurship. International Journal of Technology Management, 7(1-2): 129-139.

Allen, K. R. 2003. Bringing new technology to market. New Jersey: Prentice-Hall.

Altenburg, T., Schmitz, H., \& Stamm, A. 2008. Breakthrough China's and India's transition from production to innovation. World Development, 36(2): 325-344.

Alvarez, S. A., \& Busenitz, L. W. 2001. The entrepreneurship of resource-based theory. Journal of Management, 27(6): 755-775. 
Antoncic, B., \& Prodan, I. 2008. Alliances, corporate technological entrepreneurship and firm performance: Testing a model on manufacturing firms. Technovation, 28: 257-265.

Baark, E. 2001. Technology and entrepreneurship in China: Commercialization reforms in the science and technology sector. Review of Policy Research, 18(1): 112-129.

Bahrami, H., \& Evans, S. 1995. Flexible recycling and high-technology entrepreneurship. California Management Reviews, 37(3): 62-89.

Barney, J. B. 2007. The future of resource-based theory. In J. B. Barney, \& D. N. Clark (Eds.), Resource-based Theory: Creating and sustaining competitive advantage: 17. New York: Oxford University Press.

Brown, J. S., \& Duguid, P. 2001. Knowledge and organization: A social-practice perspective. Organization Science, 12(2): 198-213.

Burgelman, R. A., Christensen, C. M., \& Wheelwright, S. C. 2004. Strategic management of technology and innovation. New York: McGraw Hill.

Burt, R. 1997. The contingent value of social capital. Administrative Science Quarterly, 42: 339-365.

Casson, M. 1982. The entrepreneur. Totowa, NJ: Barnes \& Noble Books.

Castrogiovanni, G. J. 1991. Environmental munificence: A theoretical assessment. The Academy of Management Review, 16(3): 542-565.

Chen, Y., \& Yuan, Y. 2007. The innovation strategy of firms: Empirical evidence from the Chinese high-tech industry. Journal of Technology Management in China, 2(2): 145-153.

Cefis, E., \& Ciccarelli, M. 2005. Profit differentials and innovation. Economics of Innovation and New Technology, 14(1-2): 43-61.

Cohen, W. M., \& Levinthal, D. A. 1990. Absorptive capacity: A new perspective on learning and innovation. Administrative Science Quarterly, 35: 128-152.

Cooper, A. C. 2001. Networks, alliances and entrepreneurship. In M. A. Hitt, R. D. Ireland, S. M. Camp, \& D. L. Sexton (Eds.), Strategic entrepreneurship: Creating a new integrated mindset. Oxford: Blackwell.

Covin, J. G., \& Slevin, D. P. 1991. A conceptual model of entrepreneurship as firm behavior. Entrepreneurship Theory and Practice, 7: 25.

Dobson, W., \& Safarian, A. 2008. The transition from imitation to innovation: An enquiry into China"s evolving institutions and firm capabilities. Journal of Asian Economics, 19(4): 301-311.

Doganova, L., \& Eyquem-Renault, M. 2009. What do business models do? Innovation devices in technology entrepreneurship. Research Policy, 38: 1559-1570.

Dorf, R. C., \& Byers, T. H. 2005. Technology ventures: From idea to enterprise. New York: McGraw-Hill.

Eisenhardt, K. M., \& Martin, J. A. 2000. Dynamic capabilities: What are they? Strategic Management Journal, 21(10-11): 1105-1121.

Elfring, T., \& Hulsink, W. 2003. Networks in entrepreneurship: The case of high-technology firms. Small Business Economics, 21: 409-422.

Gans, J., \& Stern, S. 2003. The product market and the market for "ideas": Commercialization strategies for technology entrepreneurs. Research Policy, 32: 333-350.

Geroski, P., \& Machin, S., \&Van Reenen, J. 1993. The profitability of innovating firms. Journal of Economics, 24: 198-211.

Geletkanycz, M. A., \& Hambrick, D. C. 1997. The external ties of top executives: Implications for strategic choices and performance. Administrative Science Quarterly, 42: 654-681.

Granovetter, M. 1973. The strength of weak ties. American Journal of Sociology, 78(6): $1360-1380$. 
Gregorio, D. D., \& Shane, S. 2003. Why do some universities generate more start-ups than others? Research Policy, 32(2): 209-227.

Guan, J., Yam, R., Tang, E., \& Lau, A. 2006. Innovation strategy and performance during economic transition: Evidences in Beijing, China. Research Policy, 38: 802-812.

Gulati, R., Nohria, N., \& Zaheer, A. 2000. Strategic networks. Strategic Management Journal. 21(3): 203-215.

Hindle, K., \& Yencken, J. 2004. Public research commercialization, entrepreneurship and new technology based firms: An integrated model. Technovation, 24(10): 793-803.

Hitt, M. A., Ireand, R. D., Camp, S. M., \& Sexton, D. L. 2001. Strategic entrepreneurship entrepreneurial strategies for wealth creation. Strategic Management Journal, 22(6-7): 479-491.

Ireland, D. R., \& Webb, J. W. 2007. Strategic entrepreneurship: Creating competitive advantage through streams of innovation. Business Horizons, 50: 49-59.

Kenney, M., \& Von Burgh, U. 1999. Technology, entrepreneurship and path dependence: Industrial clustering in Silicon Valley and Route 128. Industrial and Corporate Change, 8(1): $67-103$.

Kirzner, I. 1997. Entrepreneurial discovery and the competitive market process: An Austrian approach. Journal of Economic Literature, 36: 60-85.

Li, H., \& Atuahene-Gima, K. 2001. Product innovation strategy and the performance of new technology ventures in china. Academy of Management Journal, 44(6): 1123-1134.

Li-Hua, R., Khalil, T. 2006. Technology management in China: A global perspective and challenging issues. Journal of Technology Management in China, 1(1): 9-26.

Linton, K. C. 2006. Access to capital in China: Competitive conditions for foreign and domestic firms. Journal of International Commerce and Economics. United States: International Trade Commission.

Liu, X. 2008. China's development model: An alternative strategy for technological catch-up. Technical report, Department of International Development, University of Oxford, pp. 32.

Lumpkin, G. T., \& Dess, G. G. 1996. Clarifying the entrepreneurial orientation construct and linking it to performance. Academy of Management Review, 21: 135-172.

Miller, D. 1983. The correlates of entrepreneurship in three types of firms. Management Science, 29: 770-791.

North, D. 1990. Institutions, institutional change, and economic performance. Cambridge, MA: Harvard University Press.

OECD. 2008. OECD reviews of innovation policy China. Technical report, OECD.

Olivier, M. 2009. The role of angel funds in early stage start-ups. In C. Petti (Ed.), Cases in technological entrepreneurship: Converting ideas into value: 67-79. Northampton, MA: Edward Elgar.

Petti, C. 2009. Cases in technological entrepreneurship: Converting ideas into value. Northampton, MA: Edward Elgar.

Petti, C., \& Zhang, S. 2011. Factors influencing technological entrepreneurship capabilities: Towards an integrated research framework for Chinese enterprises. Journal of Technology Management in China, Forthcoming.

Phan, P., \& Foo, M. 2004. Technological entrepreneurship in emerging regions. Journal of Business Venturing, 19(s1): 1-5.

Roberts, P. W. 1999. Product innovation, product-market competition and persistent profitability in the U.S. pharmaceutical industry. Strategic Management Journal, 20: 655-670.

Robertson, P., \& Von Tunzelmann, N. 2009. Innovation in low-and-medium-technology 
industries. Research Policy, 38: 441-446.

Rumelt, R. P., Schendel, D., Teece, D. J. 1994. Fundamental issues in strategy. In R. P.Rumelt, D. Schendel, \& D. J. Teece (Eds.). Fundamental issues in strategy: A research agenda: 9-47. Boston, MA: Harvard Business School Press.

Saxenian, A. L. 2006. The new argonauts: Regional advantage in a global economy. Cambridge, MA: Harvard University Press.

Schaaper, M. 2009. Measuring China's innovation system: National specificities and international comparisons. STI Working Paper 2009/1, OECD.

Schendel, D., \& Hitt, M. A. 2007. Introduction to volume 1. Strategic Entrepreneurship Journal, 1: 1-6.

Shane, S., \& Venkataraman, S. 2000. The promise of entrepreneurship as a field of research. Academy of Management Review, 25(1): 217-226.

Shane, S., \& Venkataraman, S. 2003. Guest editors' introduction to the special issue on technology entrepreneurship. Research Policy, 32: 181-184.

Smilor, R. W., Gibson, D. V., \& Dietrich, G. B. 1999. University spin-out companies: Technology start-ups from UT-Austin. Journal of Business Venturing, 5(1): 63-76.

Smilor, R. W., Gibson, D. V., \& Kozmetsky, G. 1989. Creating the technolis: High-technology development in Austin, Texas. Journal of Business Venturing, 4(1): $49-67$.

Suzuki, K., Sang-Hoon, K., \& Zong-Tae, B. 2002. Entrepreneurship in Japan and Silicon Valley: A comparative study. Technovation, 22: 595-606.

Teece, D. J., \& Pisano, G. 1994. The dynamic capabilities of enterprises: An introduction. Industrial and Corporate Change, 3(3): 537-556.

Teece, D. J., Pisano, G., \& Shuen, A. 1997. Dynamic capabilities and strategic management. Strategic Management Journal, 18(7): 509-533.

Tomes, A., Erol, R., \& Amstrong, P. 2000. Technological entrepreneurship integrating technological and product innovation. Technovation, 20: 115-127.

Tsai, W. 2000. Social capital, strategic relatedness and the formation of intraorganizational linkages. Strategic Management Journal, 21(9): 925-939.

Tushman, M., \& Andeson, P. 1997. Managing strategic innovation and change: A collection of readings. New York: Oxford University Press.

Venkatraman, S., \& Sarasvathy, S. D. 2001. Strategy and entrepreneurship: Outlines of an untold story. In M. A. Hitt, E. Freema, \& J. S. Harrison (Eds.), Handbook of Strategic Management: 650-668. Oxford: Blackwell.

Xie, W., \& White, S. 2006. From imitation to creation: The critical yet uncertain transition for Chinese firms. Journal of Technology Management in China, 1(3): 229-242.

Wang, Y., Hing-Po, L., Quan, Z., \& Xue, Y. 2006. How technological capability influences business performance: An integrated framework based on the contingency approach. Journal of Technology Management in China, 1(1): 27-52.

Wang, Y., Hing-Po, L., \& Yang, Y. 2004. The constituents of core competencies and firm performance: Evidence from high-technology firms in china. Journal of Engineering and Technology Management, 21: 249-280.

Wilsdon, J., \& Keeley, J. 2007. China: The next science superpower? Technical report, DEMOS.

Wu, X., Ma, R., \& Shi, Y. 2010. How do latecomer firms capture value from disruptive technologies? A secondary business-model innovation perspective. IEEE Transactions on Engineering Management, 57(1): 51-62.

Xinhua News Agency. 2009. Beijing gets power from chicken farm. Retrieved May 4, 2010, from http://news.xinhuanet.com/english/2009-05/04/content 11308629.htm 
Yu, J., Stough, R., \& Nijkamp, P. 2009. Governing technological entrepreneurship in China and the West. Public Administration Review, 69(s1): 95-100.

Zahra, S. A., \& George, G. 2002. Absorptive capacity: A review, reconceptualization and extension. Academic Management Review, 27(2):185-203.

Zhang, G., Xuebing, P., \& Li, J. 2008. Technological entrepreneurship and policy environment: A case of China. Journal of Small Business and Enterprise Development, 15(4): 733-751.

Zhang, J., Liu, Z., \& Zheng, J. 2009. Key influencing factors of innovation activities in China's manufacturing enterprises: Evidence from Jiangsu Province. Frontiers of Business Research in China, 3(1): 145-169.

Zirger, B. J., \& Maidique, M. A. 1990. A model of new product development: An empirical test. Management Science, 36: 867-883. 